\title{
SHORT COMMUNICATIONS КРАТКИЕ СООБЩЕНИЯ PROTECTING SMALL POPULATIONS OF RARE SPECIES. CASE STUDY ON DACTYLORHIZA VIRIDIS (ORCHIDACEAE) IN FANCOTT WOODS AND MEADOWS SSSI, BEDFORDSHIRE, UK
}

\author{
Irina Tatarenko ${ }^{1}$, Mike Dodd ${ }^{1}$, Hilary Wallace ${ }^{2}$, Graham Bellamy ${ }^{3}$, Andy Fleckney ${ }^{4}$ \\ ${ }^{1}$ Open University, United Kingdom \\ e-mail:Irina.Tatarenko@open.ac.uk,Michael.Dodd@open.ac.uk \\ ${ }^{2}$ Ecological Survey (Bangor), United Kingdom \\ e-mail: hilary@ecologicalsurveys.co.uk \\ ${ }^{3}$ Dryad Wildlife, United Kingdom \\ e-mail:graham@gcbellamy.plus.com \\ ${ }^{4}$ Wildlife Trust for Bedfordshire, Cambridgeshire and Northamptonshire, United Kingdom \\ e-mail: Andy.Fleckney@wildlifebcn.org
}

Received: 27.02.2020. Revised: 16.05.2020. Accepted: 23.05.2020.

\begin{abstract}
Dactylorhiza viridis is a small orchid species, sensitive to competition with dense and tall herbaceous vegetation. Its populations in Europe and in the UK have been declining over the last century. Small, isolated populations have remained in Protected Areas. The population of the species in Fancott Woods and Meadows Site of Special Scientific Interest (SSSI) was studied in 2011-2019. The number of orchid plants varies substantially from year to year, but the areas occupied by the population remain the same. Fruit production is high. The population is under threat from herbivores and from competition with tall vegetation on the meadow. Expansion of the vigorous herb Filipendula ulmaria was recorded on the meadow in 2009 that negatively affected the rare plant community. Additional management of an early hay cut was implemented on the meadow as a trial. A botanical survey of managed and control plots showed a reduction in the vigorous herbs, an increase in species number in the cut plots and a resulting more open sward. The orchid population also benefits from a more open sward. The management of the site is the key to the survival of this small orchid population.
\end{abstract}

Key words: conservation, competition, fruit set, hay cut, herbivory, orchid population, site management

\section{Introduction}

The loss of semi-natural grasslands became extensive in Europe including the UK due to intensified agriculture in the XX century (Jefferson $\&$ Pinches, 2009). Small fragments of species-rich meadows which survived under traditional management are protected in nature reserves and sites of special scientific interest (SSSI) (Rothero et al., 2016). Along with an increase in fragmentation of remaining habitats, populations of rare species appeared to be under more threat (Minasiewicz et al., 2018). Populations of orchids are particularly vulnerable, requiring specific links with pollinators and mycorrhizal fungi to complete their life cycle (Honnay \& Jacquemyn, 2007). Although mycorrhizal specificity is low in Dactylorhiza, and the fungi have a broad geographic distribution, their actual occurrence is controlled by specific habitat conditions (Jacquemyn et al., 2016). Orchid species are very weak competitors, quickly disappearing under dense swards. On sites with relatively bulky and tall vegetation, orchid populations are often very small and even more vulnerable (e.g. Tatarenko, 1991;
Adamowski, 2006). Conservation management of sites hosting small and isolated orchid populations should be very consistent and focusing on the protected species (Swarts \& Dixon, 2009).

Dactylorhiza viridis (L.) R.M.Bateman, Pridgeon \& M.W.Chase (Orchidaceae) is a species with a very wide geographical and ecological range (Vakhrameeva et al., 2008). Its circumboreal distribution covers most of Eurasia and North America, from the extreme North to South. The species grows in a wide altitudinal range from floodplains to high mountains, up to $3000-4000 \mathrm{~m}$ a.s.l. (Nilsson, 1979). Dactylorhiza viridis grows in tundra in the northern parts of the range (Tolmachev, 1963), in a variety of woodlands and meadows, including alpine and subalpine ones (Vakhrameeva et al., 2008). In the UK, the species has been recorded in grasslands, from dry communities on chalk to wet floodplain meadows on calcareous gravel beds (Online Atlas, 2019). The species is linked to calcium-rich soils (Willems \& Melser, 1998), but can also be found on more acid soils (Ellenberg, 1988; Vakhrameeva et al., 2008). 
Although not under threat of extinction, there have been population decreases in the European part of the species range. In the Netherlands only two populations remain out of 55 present before 1950 (Willems \& Melser, 1998). In the UK, the most substantial decrease happened by 1930s, with continuous decline in later years (Online Atlas, 2019). It is listed as vulnerable on the Red Data List for England (Stroh et al., 2014). A small population of the species was studied in Fancott Meadow during the period 2011-2019.

To give context to this Fancott population the distribution of both the orchid species and habitat were examined in the surrounding area. Species occurrence was traditionally recorded in $10 \times 10 \mathrm{~km}$ grid squares (hectads, according to BSBI, 2020) across the UK. In 1930 a total of 14 of the closest 25 hectads to Fancott, contained D. viridis, but by 2010-2019 only four of these hectads contained the species. In 1930 well over half of the land area in these 25 hectads was meadowland (https://digimap. edina.ac.uk/roam/map/environment), and this meadowland was largely continuous. By 1990 much more detailed information on the habitat was available, none of the $25001 \times 1 \mathrm{~km}$ grid squares within this area were dominated by meadowland (Fuller et al., 1994), and the small areas of meadowland that did still remain, visible on the even more detailed $25 \times 25$ $m$ habitat map, were highly fragmented. This reflects the UK context where $97 \%$ of species rich meadows were lost between 1930 and 1994 (Fuller, 1987), and the loss has continued (Ridding et al., 2015). Fancott Woods and Meadows is a protected area designated as a site of Special Scientific Interest in Bedfordshire, the UK (Fancott Woods and Meadows, 2020). The site was designated because of ancient unimproved meadow traditionally managed for hay and grazing, which accommodate the rare plant communities MG4 and MG5 types according to British National Vegetation Classification (Rodwell, 1992). The MG4 plant community has a European protected status as «Moist or wet mesotrophic to eutrophic hay meadow» (E3.4a), which are classed as Endangered on the European Red List of habitats (Janssen et al., 2016). The site has been managed mainly by grazing. After the wet summer of 2008, it became dominated by Filipendula ulmaria (L.) Maxim., a tall herb which supressed small and less competitive species causing a decline in plant diversity on the site (Wallace \& Tatarenko, 2018).

In 2011-2018, the effect of early hay cut on vegetation, in addition to grazing the site in June August, was investigated in a trial carried out by the
Bedfordshire, Cambridgeshire and Northamptonshire (BCN) Wildlife Trust and the Open University. The main purpose of the trial was to work out an effective way of controlling the vigorous vegetation in order to maintain the protected plant community on the site. The small and isolated population of $D$. viridis in Fancott Meadow was also expected to benefit from the additional management on the site. In this account we assessed the current state of the orchid population and discuss factors affecting its survival in relation to importance of the site management.

\section{Material and Methods}

Fancott Meadows and Woods SSSI is a 13 ha nature reserve in Bedfordshire, UK (co-ordinates: $\left.51.937017^{\circ} \mathrm{N}, 0.509712^{\circ} \mathrm{W}\right)$.

The hay cut trial included three $10 \times 10 \mathrm{~m}$ plots, which were cut in June and then aftermath grazed. Three control plots of the same size were grazed from June onwards with no hay cut. Cut and control (uncut) treatments were botanically surveyed on 15 randomly positioned quadrats, five quadrats within each of $10 \times 10 \mathrm{~m}$ plots (Fig. 1). All plant species were recorded in $1 \times 1 \mathrm{~m}$ quadrats, species abundance was estimated as a projective cover. Species richness was measured as the number of species per $1 \mathrm{~m}^{2}$. Ellenberg indicator values (Ellenberg, 1988) were calculated to estimate dynamics of soil nutrients.

Plants of Dactylorhiza viridis were recorded with high accuracy (up to $1 \mathrm{~cm}$ ) differential GPS Leica RX1200 in 2013 and 2019. The individual plant height was measured together with the number of leaves and number of flowers versus green pods. Historic data of monitoring orchid population in 1978-2018 were kindly provided by BCN Wildlife Trust.

Data analysis included one-way ANOVA test for changes in vegetation. Fruiting success was calculated as the percentage of flowers that set pods per spike. Plant names are given after Clapham et al. (1962) and Bateman et al. (1997).

\section{Results}

There are two sites for the D. viridis population in Fancott Meadow (Fig. 1). The distance between them is about $25 \mathrm{~m}$. In 2017, an individual was noted near quadrats $18-20$ of the hay-cut trial; another individual was recorded in quadrat 22 (Fig. 1) in the 2018 survey. Both plants failed to re-emerge in the 2019 survey. Four plants were recorded in the site with high accuracy differential GPS in 2013 (Fig 1.); none of them were found in the 2019 revisit of their exact positions. 


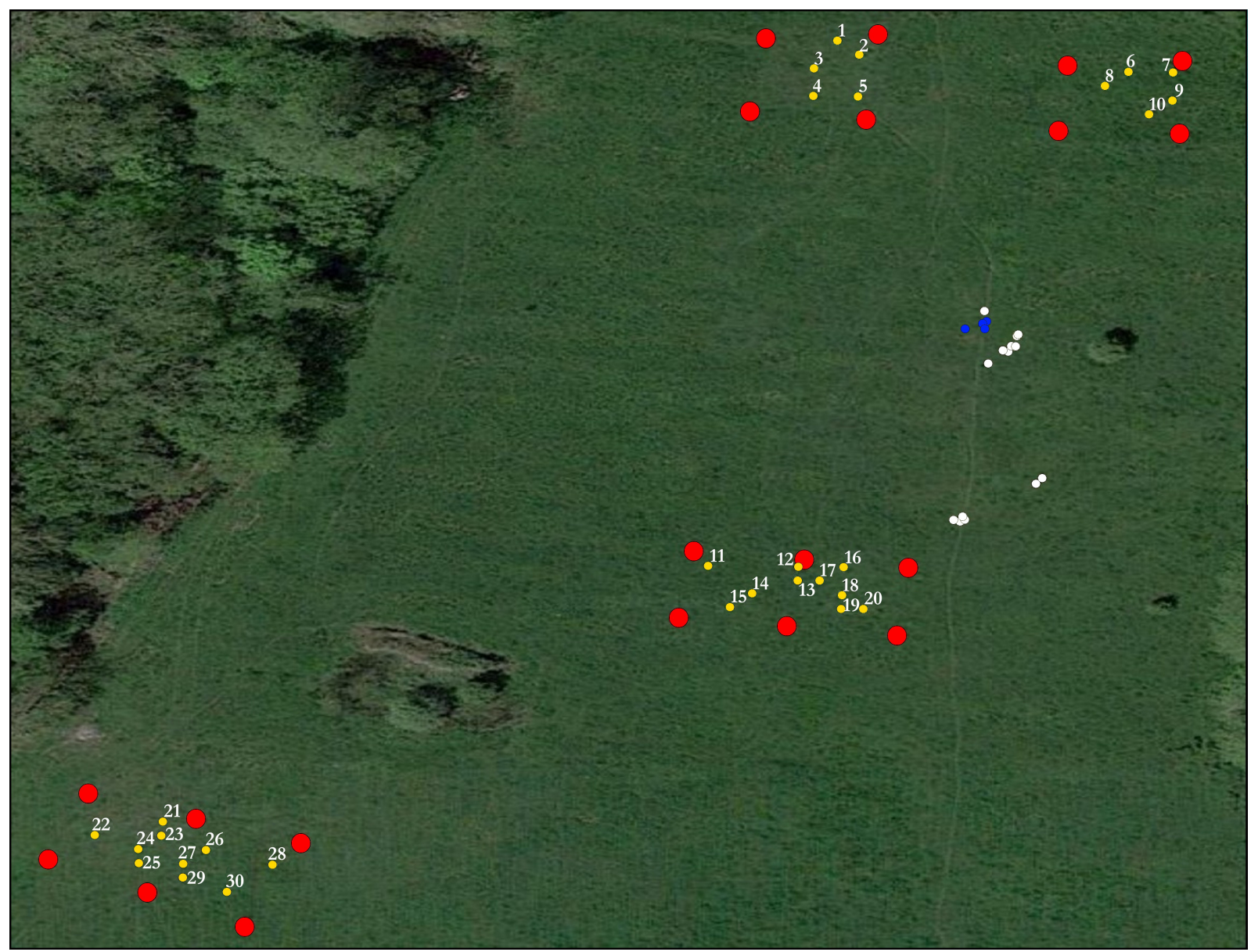

Fig. 1. Locations of individual plants of Dactylorhiza viridis and hay-cut trial plots in Fancott Meadow. Designations: red dots mark the corners of trials; yellow dots mark locations of survey quadrats $(1-5,16-20,21-25$ - hay cut trails; 6-10, 11-15, 26-30 - uncut control); blue dots mark plants of $D$. viridis recorded in 2013; white dots are plants of $D$. viridis recorded in 2019. Background imagery: C Getmapping plc, Infoterra Ltd \& Bluesky.

Records from previous years (Fig. 2) suggest a high fluctuation rate in flowering individuals. Twelve flowering and two vegetative plants were recorded on the site in June 2019. Eight of them set pods, four flowering plants and one vegetative were eaten by herbivorous animals. Dactylorhiza viridis plants were 8-22 $\mathrm{cm}$ tall, that was shorter than the surrounding vegetation, which average height was $34 \mathrm{~cm}$. The number of flowers per spike varied from 8 to 25 , most flowers were pollinated and formed green pods (Table 1).

A botanical survey of the 30 quadrats in the hay-cut trial showed statistically significant negative changes in the projective cover of the dominant species Fillipendula ulmaria in the «cut» plots (Table 2). The species showed $38 \%$ of decline in the «cut» plots comparing to $9 \%$ increase in the control «uncut» plots. Trifolium pratense L. and Carex flacca Schreb. gained most benefits from the hay cut, increasing their cover in the «cut» plots (Table 2), while Dactylis glomerata L. negatively reacted to the hay cut. Cirsium palustre (L.) Scop. spread out into the new locations, disappearing from the control plots. Overall, the species richness in the cut plots was higher than in the control plots (in average, 25 vs. 17 species per $1 \mathrm{~m}^{2}$ ) in 2018 (ANOVA, $\mathrm{p}=0.001)$ (Wallace \& Tatarenko, 2018).

Changes in Ellenberg indicator values for soil nutrients (Fig. 3) were found to be significant between «cut» treatment and «control» plots (ANOVA, p < 0.001) (Wallace \& Tatarenko, 2018). A reduction of the nutrient level in the «cut» plots below $\mathrm{N}=5$ indicated soil condition suitable for the smaller species and more sparse vegetation.

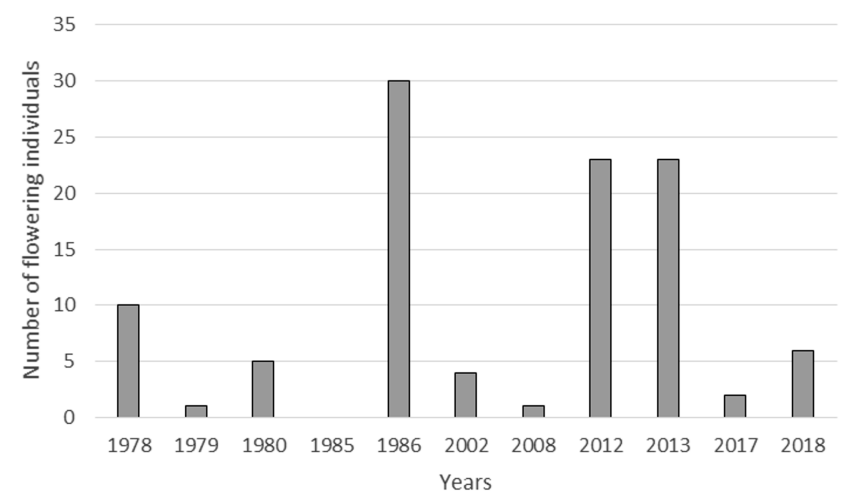

Fig. 2. Maximum counts of Dactylorhiza viridis on Fancott Meadow. Data collected by BCN Wildlife Trust. 
Table 1. Characteristics of flowering plants of Dactylorhiza viridis in Fancott Meadow in 2019

\begin{tabular}{|l|c|c|c|c|}
\hline & $\begin{array}{c}\text { Number } \\
\text { of flowers } \\
\text { in a spike }\end{array}$ & $\begin{array}{c}\text { Number } \\
\text { of green pods }\end{array}$ & $\begin{array}{c}\text { Plant } \\
\text { height, cm }\end{array}$ & $\begin{array}{c}\text { Fruiting } \\
\text { success, \% }\end{array}$ \\
\hline Mean & 16.4 & 14.1 & 17.4 & 86.8 \\
\hline $\begin{array}{l}\text { Standard } \\
\text { deviation }\end{array}$ & 4.8 & 4.2 & 4.0 & 6.8 \\
\hline $\begin{array}{l}\text { Number of } \\
\text { replicates }\end{array}$ & 8 & 8 & 8 & 8 \\
\hline
\end{tabular}

Table 2. Changes in vegetation on two types of plots in the hay-cut trial in Fancott Meadow, 2011-2018

\begin{tabular}{|c|c|c|}
\hline \multirow{3}{*}{ Species } & \multicolumn{2}{|c|}{ Treatment } \\
\hline & Cut & Uncut \\
\hline & \multicolumn{2}{|c|}{$\begin{array}{c}\text { Changes in projective cover } \\
\text { over } 7 \text { years of trail, } \%\end{array}$} \\
\hline Filipendula ulmaria (L.) Maxim. & -38.33 & 9.2 \\
\hline Poa trivialis $\mathrm{L}$. & -3 & 8.13 \\
\hline Anthoxanthum odoratum L. & -1.87 & 1.67 \\
\hline Lysimachia nummularia $\mathrm{L}$. & -0.67 & 9.07 \\
\hline Alopecurus pratensis L. & -0.53 & 2.87 \\
\hline Centaurea nigra $\mathrm{L}$. & 4.53 & -3.53 \\
\hline Juncus articulatus L. & 5.47 & 0 \\
\hline Plantago lanceolata $\mathrm{L}$. & 6.2 & -0.13 \\
\hline Ranunculus acris L. & 7.27 & 3.47 \\
\hline Ranunculus repens $\mathrm{L}$. & 8.13 & 1.33 \\
\hline Calliergonella cuspidata Loeske & 8.47 & 0.07 \\
\hline Trifolium pratense $\mathrm{L}$. & 12.33 & 0.27 \\
\hline Carex flacca Schreb. & 16.6 & 2.73 \\
\hline
\end{tabular}

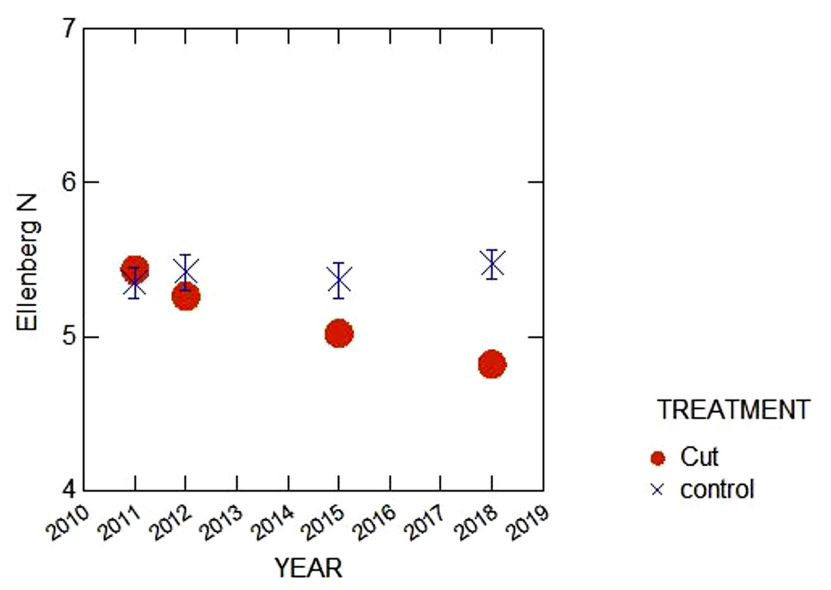

Fig. 3. Changes in mean Ellenberg indicator values for soil nutrients in 'cut' and control plots in the hay-cut trail in Fancott Meadow in 2011-2018. Values are means, based on 15 quadrat records for each treatment per year, bars represent one standard error of the mean (adapted from Wallace \& Tatarenko, 2018).

\section{Discussion}

The population of Dactylorhiza viridis in Fancott Meadow is very small, with a maximum of 30 plants recorded in any one year (Fig. 2). Regarding the population size, there is nothing unusual for this species to have small populations across its wide range (Vakhrameeva et al., 2008; Plotnikova et al., 2010). However, a small number of plants makes isolated populations particularly vulnerable to occasional disturbances and local extinction. Herbivory can cause substantial damage to a population that relies on reproduction by seeding. More than $30 \%$ of the plants of D. viridis in Fancott Meadow, which were flowering and vegetating in 2019, were eaten by grazers. Orchid green pods are known to be very attractive to herbivorous invertebrates (Vakhrameeva et al., 2008). Seed production of an entire population can be devastated by grazing activity, as we observed in another orchid species Pogonia japonica Rchb.f. (Tatarenko, personal observation).

The Fancott population of the species displayed a very high rate of fruiting success (Table 1). Dactylorhiza viridis rewards its pollinators with nectar. Common known pollinators of the species are Coleoptera and Hymenoptera (van der Cingel, 1995). Very recently, ants were recorded carrying, on average, three pollinaria of $D$. viridis on their head (Claessens \& Seifert, 2018). Ant nests are a common feature of ancient meadows in the UK. Fancott Meadow accommodates several large ant nests in the area where orchids occur. As orchids' flower spikes are not tall and substantially obscured by surrounding vegetation, it seems logical that the flowers might be pollinated by insects which do not use visual attraction to the flowers. The ants are likely to contribute to the pollination success of this small orchid population, however, it should be investigated further.

The pollination success is critically important for populations of $D$. viridis, as the species reproduces mainly by seeds (Willems \& Melser, 1998). Seeds germinate within 1-2 months, some seeds retain their ability to germinate for a year, but longer seed dormancy was not recorded (Tatarenko et al., 2002). In the Netherlands, the species seemed to build up sufficient resources in mycorhizomes formed from seeds germinated below ground. There is no data on how long the plant takes to appear above ground after germination. According to Willems \& 
Melser (1998), on average $43 \%$ of plants produced inflorescence in the year in which they first emerge above ground. The species is short lived with a half-life of cohorts of between 1.0 to 2.4 years from its first appearance above the ground (Willems \& Melser, 1998).

Prolonged dormancy is not a characteristic of $D$. viridis; plants were found staying dormant occasionally and for no longer than one year (Willems \& Melser, 1998). These details of the species life cycle explain the highly dynamic nature of its populations, also observed in Fancott Meadow (Fig. 2). The number of plants in year (a) relies mainly on the seed production rate in the year (a-2) or (a-3), and sparse vegetation/ground surface availability for the seeds to germinate in the same year. Plants of this species form a large number of seeds: from 1472 per pod (Khomutovskii, 2012) to 2300 per pod (Willems \& Melser, 1998). However, the probability of them landing on a ground spot with suitable soil fungi to initiate seed germination, is very low (Tatarenko, 2002).

This explains the critical importance of site management in keeping the vegetation sward low and open (Willems \& Melser, 1998). A sparse vegetation cover and absence of litter are two major requirements for the species successful reproduction. The hay-cut trial on Fancott Meadow decreased soil nutrients and sward density in the treated plots. The dominance of Filipendula ulmaria and grasses decreased significantly in the cut plots. Smaller species, like Carex flacca and Ranunculus acris L. are not strong competitors which would restrict orchid growth amongst them. The increase of Plantago lanceolata L. and Trifolium pratense on the cut plots suggests the availability of bare ground and easy access of the seeds to the ground surface. This can be obstructed by the expanding cover of Calliergonella cuspidata Loeske, however, the presence of this moss is season- and weather-dependent (Tatarenko, personal observation). The appearance of $D$. viridis individuals in the cut areas in 2017 and 2018 indicates that the orchid population could expand across the site if the vegetation is managed by suitable hay cuts. It would seem desirable therefore to re-introduce an annual hay cut followed by aftermath grazing to the entire site.

\section{Conclusions}

The rare orchid species Dactylorhiza viridis forms a small population on an ancient pro- tected floodplain species-rich meadow in Bedfordshire, the UK. The population numbered 14 individual plants in 2019, a third of which was devastated by herbivorous animals. Fruit production was very high in the population, which is important as the species reproduces predominantly by seeds. A more open ground surface and a less dense vegetation are beneficial for the orchid population. Early hay cut trial in addition to the traditional grazing management in Fancott Meadow indicate that this type of management would be the best option for the orchid population conservation.

\section{Acknowledgements}

We thank BCN Wildlife Trust for funding and carrying out the hay cut trial. The orchid population survey and full data analysis undertaken in 2018-2019 was very kindly supported by Mrs. Rachel Webb.

\section{References}

Adamowski W. 2006. Expansion of native orchids in anthropogenous habitats. Polish Botanical Studies 22: 35-44.

Bateman R.M., Pridgeon A., Chase M.W. 1997. Dactylorhiza viridis (L.). Lindleyana 12(3): 129.

BSBI. 2020. Maps and Data from Botanical Society of Britain \& Ireland. Available from https://bsbi.org/maps-and-data

Claessens J., Seifert B. 2018. Ant pollination of Dactylorhiza viridis. Orchid Digest 82: 154-158.

Clapham A.R., Tutin T.G., Warburg E.F. 1962. Flora of the British Isles. New York: Cambridge University Press. 1269 p.

van der Cingel N.A. 1995. An Atlas of Orchid Pollination: European Orchids. USA: CRC Press. 260 p.

Ellenberg H. 1988. Vegetation ecology of Central Europe. $4^{\text {th }}$ edition. Cambridge: Cambridge University Press. 756 p.

Fancott Woods and Meadows. 2020. Fancott Woods and Meadows WTBCN Flyer. BCN Wildlife Trust. Available from https:/www.wildlifebcn.org/sites/ default/files/2019-08/FancottWoodsandMeadowsWTBCN-Flyer.pdf

Fuller R.M. 1987. The changing extent and conservation interest of lowland grasslands in England and Wales: a review of grassland surveys 1930-1984. Biological Conservation 40(4): 281-300. DOI: 10.1016/0006-3207(87)90121-2

Fuller R.M., Groom G.B., Jones A.R. 1994. The Land Cover Map of Great Britain: an automated classification of Landsat Thematic Mapper data. Photogrammetric Engineering and Remote Sensing 60: 553-562.

Honnay O., Jacquemyn H. 2007. Susceptibility of common and rare plant species to the genetic consequences of habitat fragmentation. Conservation Biology 21(3): 823-831. DOI: 10.1111/j.1523-1739.2006.00646.x 
Jacquemyn H., Waud M., Merckx V., Brys R., Tuteca D., Hedren M., Lievens B. 2016. Habitat-driven variation in mycorrhizal communities in the terrestrial orchid genus Dactylorhiza. Scientific Reports 6: 37182. DOI: $10.1038 /$ srep37182

Janssen J.A.M., Rodwell J.S., Criado M.G., Gubbay S., Haynes T., Nieto A., Sanders N., Landucci F., Loidi J., Ssymank A., Tahvanainen T., Valderrabano M.,Acosta A., Aronsson M., Arts G., Attorre F., Bergmeier E., Bijlsma R.J., Bioret F., Biţă-Nicolae C., Biurrun I., Calix M., Capelo J., Čarni A., Chytrý M., Dengler J., Dimopoulos P., Essl F., Gardfjell H., Gigante D. et al. 2016. European Red List of Habitats Part 2. Terrestrial and freshwater habitats. Brussels: European Commissioner for the Environment. Available from https://ec.europa.eu/environment/nature/ knowledge/pdf/terrestrial_EU_red_list_report.pdf

Jefferson R.G., Pinches C.E. 2009. The conservation of floodplain meadows in Great Britain: an overview. Fritillary 5: 4-17.

Khomutovskii M.I. 2012. Seed production in Coeloglossum viride (L.) C. Hartm. and Orchis militaris L. in natural monument «Seltsovskie Zalomki» (Tver region). In: Actual issues of studies and vonservation of biodiversity in the Upper Volga region. Ivanovo: Ivanovo State University. P. 79-85. [In Russian]

Minasiewicz J., Znaniecka J.M., Górniak M., Kawiński A. 2018. Spatial genetic structure of an endangered orchid Cypripedium calceolus (Orchidaceae) at a regional scale: limited gene flow in a fragmented landscape. Conservation Genetics 19(6): 1449-1460. DOI: 10.1007/s10592-018-1113-4

Nilsson S. 1979. Orchids of Northern Europe. Middlesex: Penguin Books Ltd. 146 p.

Online Atlas. 2019. Coeloglossum viride. In: Online Atlas of the British and Irish Flora. Available from https://www. brc.ac.uk/plantatlas/plant/coeloglossum-viride

Plotnikova I.A., Degteva S.V., Dubrovskiy Yu.A. 2010. Ecology and population structure of Coeloglossum viride (Orchidaceae) in Northern Urals. Rastitelnye Resursy 46(4): 35-46. [In Russian]

Ridding L.E., Redhead J.W., Pywell R.F. 2015. Fate of semi-natural grassland in England between 1960 and 2013: A test of national conservation policy. Global Ecology and Conservation 4: 516-525. DOI: 10.1016/j.gecco.2015.10.004
Rodwell J.S. 1992. British plant communities. Vol. 3: Grasslands and montane communities. Cambridge: Cambridge University Press. 552 p.

Rothero E., Lake S., Gowing D. (Eds.). 2016. Floodplain Meadows - Beauty and Utility. A Technical Handbook. Milton Keynes: Floodplain Meadow Partnership. 104 p.

Stroh P.A., Leach S.J., August T.A., Walker K.J., Pearman D.A., Rumsey F.J., Harrower C.A., Fay M.F., Martin J.P., Pankhurst T., Preston C.D., Taylor I. 2014. A Vascular Plant Red List for England. Bristol: Botanical Society of Britain and Ireland. 193 p.

Swarts N., Dixon K. 2009. Terrestrial orchid conservation in the age of extinction. Annals of Botany 104(3): 543 556. DOI: $10.1093 / \mathrm{aob} / \mathrm{mcp} 025$

Tatarenko I.V. 1991. Coenopopulation dynamics of the three orchid species under different degrees of anthropogenic pressure. In: The topical problems of phytobiota protection in the west regions of Ukraine. Lvov. P. 109 112. [In Russian]

Tatarenko I.V. 2002. Intensity of mycorrhizal infection in some orchid populations in Japan. In: P. Kindlmann, J.H. Willems, D.F. Whigham (Eds.): Trends and fluctuations and underlying mechanisms in terrestrial orchid populations. Leiden: Backhuys Publishers. P. 167-183.

Tatarenko I.V., Kondo K., Futagawa K., Suzuki R. 2002. Experimental studies of orchid seed germination in nature. In: Biodiversity and Bioresources of the Urals and surrounding territories. Orenburg. P. 80-82.

Tolmachev A.I. 1963. Family Orchidaceae. In: Arctic Flora of the USSR. Vol. 6. Moscow; Leningrad: Publisher of AS USSR. P. 73-85. [In Russian]

Vakhrameeva M.G., Tatarenko I.V., Varlygina T.I., Torosyan G.K., Zagulskii M.N. 2008. Orchids of Russia and adjacent countries. Ruggell: A.R.G. Gantner Verlag K.G. 690 p.

Wallace H., Tatarenko I. 2018. Fancott vegetation change, 2011-2018. Report to BCN Wildlife Trust. London: The Open University. $16 \mathrm{p}$.

Willems J.H., Melser C. 1998. Population dynamics and life-history of Coeloglossum viride (L.) Hartm.: an endangered orchid species in The Netherlands. Botanical Journal of the Linnean Society 126(1-2): 83-93. DOI: 10.1006/boj1.1997.0146 
СОХРАНЕНИЕ МАЛОЧИСЛЕННЫХ ПОПУЛЯЦИЙ РЕДКИХ ВИДОВ. ИССЛЕДОВАНИЕ DАСТYLORHIZA VIRIDIS (ORCHIDACЕAЕ) НА ОХРАНЯЕМОМ ЛУГУ ФАНКОТТ
В ГРАФСТВЕ БЕДФОРДШИР (ВЕЛИКОБРИТАНИЯ)

\author{
И. Татаренко ${ }^{1}$, М. Додд ${ }^{1}$, Х. Уоллес ${ }^{2}$, Г. Беллами ${ }^{3}$, А. Флекни ${ }^{4}$ \\ ${ }^{1}$ Открытый университет, Великобритания \\ e-mail:Irina.Tatarenko@open.ac.uk,Michael.Dodd@open.ac.uk \\ ${ }^{2}$ Бангорский иентр экологических исследований, Великобритания \\ e-mail: hilary@ecologicalsurveys.co.uk \\ З Дриад Уайлдлайф, Великобритания \\ e-mail: graham@gcbellamy.plus.com \\ ${ }^{4}$ Фонд охраны природы Бедфордшир, Кэмбриджсшир и Носхамптоншир, Великобритания \\ e-mail: Andy.Fleckney@wildlifebcn.org
}

Dactylorhiza viridis - это небольшая по размерам орхидея, чувствительная к конкуренции со стороны густой и высокой растительности. Популяции этого вида сокращаются в Европе и Великобритании на протяжении последнего столетия. Маленькие изолированные популяции остаются на охраняемых территориях. Наблюдения за популяцией вида на охраняемом лугу Фанкотт в Великобритании проводились в 2011-2019 гг. Численность особей в популяции значительно варьирует в разные годы, однако участок, занимаемый ею, остается примерно постоянным. Плодообразование в популяции высокое. Среди факторов окружающей среды, представляющих угрозу для популяции, можно выделить травоядных животных и конкуренцию с высокотравной растительностью в местообитании. В 2009 г. на лугу было отмечено значительное разрастание Filipendula ulmaria, которое негативно сказалось на состоянии растительного сообщества в целом. Эффект от раннего сенокошения, как дополнительной меры по регулированию растительности, был изучен на косимых участках в сравнении с контрольными. Эксперимент показал значительное сокращение высокотравных видов, формирование более открытого травостоя, а также общее увеличение видового разнообразия на косимых участках. Меньшая сомкнутость луговой растительности на экспериментальных участках предоставила возможность расселения орхидных на лугу. Регулирование растительности луга является ключевым фактором для сохранения небольшой популяции D. viridis.

Ключевые слова: конкуренция, луг, орхидная популяция, охрана природы, плодообразование, регулирование растительности, редкое сообщество, сенокошение 